\title{
Effect of Log Length on Forestry Loading and Unloading
}

\author{
Henrique Arcego $^{1}$ (D), Renato Cesar Gonçalves Robert ${ }^{1}$ (D), \\ Rafael Oliveira Brown ${ }^{1}$ \\ ${ }^{1}$ Universidade Federal do Paraná - UFPR, Curitiba/PR, Brasil
}

\begin{abstract}
This study aimed to technically evaluate loading and unloading with different wood lengths . Data used were obtained from log harvesting areas of a forestry company in southern Brazil, on operations with loblolly pine logs. The study addressed the analysis of time and motion, being divided into loading, unloading, mooring and unmooring. Four treatments with different log lengths, number of safety straps and number of sampled vehicles were analyzed. Analysis of variance and Tukey test were used to evaluate differences among treatments. Loading and unloading productivity increase of $114 \%$ and $92 \%$ was observed, respectively, when log length increased from $2.4 \mathrm{~m}$ to $7 \mathrm{~m}$. When log length increased, productivity and yield of hours/work also increased. Loading was negatively influenced by the environment where the activity was carried out.
\end{abstract}

Keywords: productivity, forest, logistics. 


\section{INTRODUCTION}

In a wood supply operation, activities are interconnected and dependent on each other. Loading is the activity that links wood harvesting to the forest transportation when the wood that is in the field is then deposited in a means of transport, and unloading is the activity that connects the activity of forest transportation to the industrial yard, according to Minette et al. (2014).

Improvements and innovations in operational procedures, forest processes, and work equipment are the objective of forest-based companies in the search for cost reduction, higher productivity, and work quality and safety, Bramucci \& Seixas (2002). Thus, according to Strandgard \& Mitchell (2015), carrying out motion studies aimed at improving operations and reducing operating costs becomes more and more important.

Machado et al. (2009) reported that the duration of the transportation operational cycle corresponds to the period in which the vehicle operates actively (on the road) and passively (loading and unloading), which is directly proportional to the route. In addition to reduction the duration of the total transportation cycle, the highest effective working time should actively be used.

The productivity of transportation vehicles and the transportation cost are directly related to loading and unloading activities. Conway (1976) quoted by Costa et al. (2003) reported that the waiting time for loading and unloading is a bottleneck and the main cause of delay in these operations.

According to Santos et al. (2009), it is necessary to reduce the loading and unloading time to increase the amount of wood transported per time unit and reduce the transportation cost. Consequently, there will be an increase in the working hours of transport vehicles and yield due to the greater number of daily trips.

In an unloading operational analysis, Alves et al. (2013) concluded that increasing log length improves operational efficiency since the crane used for unloading requires fewer movements. For Minette et al. (2014) and Santos et al. (2009), the operational efficiency of machines, the arrangement, the type of wood being transported, and the operator's skill and training can also be considered factors that influence the operation productivity. Therefore, wood loading must be well planned and carried out efficiently as it influences both productivity and transportation cost.

The technical analysis of loading and unloading operations was the aim of this work, comparing operations with log of different lengths and the number of safety straps used in each load.

\section{MATERIAL AND METHODS}

The study was carried out in forest areas of a forestry company located in Otacílio Costa-SC, in a bioclimatic zone characterized by altitudes between 800 and $1200 \mathrm{~m}$ in operations with Pinus taeda wood. According to the Köppen classification,, the climate of the region is mesothermic humid (summer with mild temperatures and frequent frosts in the winter). The average annual rainfall is $1,500 \mathrm{~mm}$, distributed throughout the months of the year.

The harvesting system used was the Full tree system, where felling and bundle formation operations are carried out by a feller-buncher and the drag of the trees up to the road edge is performed using a skidder. The processing and arrangement of logs at the roadside were performed by a harvester head. In the wood loading and unloading operation, forest loaders consisting of a tracked excavator with hydraulic drive were used. The equipment used in the loading operation consisted of the following hydraulic driven base machines (Figure 1): Caterpillar CAT 320L, Komatsu PC200, and Dosan 210x. Dosan 210x was used in the unloading operation, equipped with grapple of $1 \mathrm{~m}^{2}$ useful area in loaders and $0.8 \mathrm{~m}^{2}$ in unloaders. The working day at the company was divided into two eight-hour shifts. The loading operation was performed with own machinery (priming), while the unloading operation was carried out by service providers (outsourcing).

Technical data were collected in the stages of loading, lashing, unlashing and unloading of logs in bi-train articulated load carriers, with combined total gross weight of 57 tons (Figure 2).

Pinus taeda logs for processing had lengths of $2.40 \mathrm{~m}$ (PTP-240), $3.40 \mathrm{~m}$ (PTP-340) and $7.00 \mathrm{~m}$ (PTP-700). The loading of logs in the transportation vehicle was carried out in the longitudinal direction. Log loads of $2.40 \mathrm{~m}$ form 6 packets (bundles) on the bi-train, $\log$ loads of $3.40 \mathrm{~m}$ form 4 packets (bundles), while 


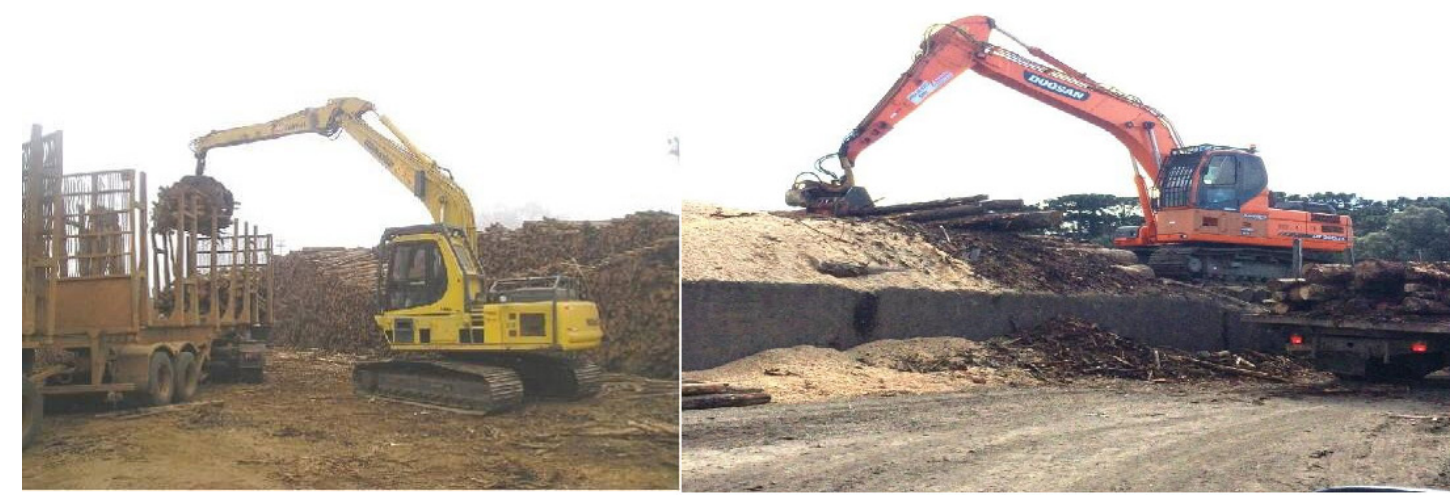

Figure 1. Komatsu PC 200 (on left), Dosan 210x (on the right) Figure 1: Komatsu PC 200 (on left), Dosan 210x (on the right).

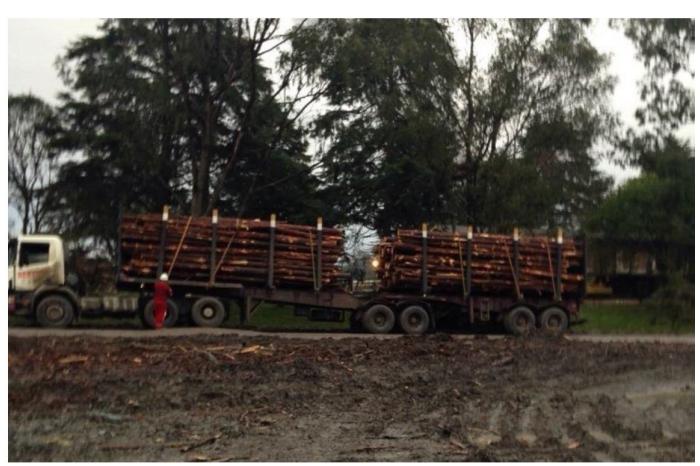

Figure 2. Bi-train truck loaded with two 7-meter log piles and driver mooring piles.

$\log$ loads of $7.00 \mathrm{~m}$ form 2 packets (bundles) on the bi-train. The company requires transportation service providers to use polyester safety belts in the tying of log loads in the amount of 1 belt with minimum breaking capacity of $5000 \mathrm{kgf}$ or 2 belts of $3000 \mathrm{kgf}$ each for each package.

Four treatments were carry out in the study, differentiated according to the lengths of loaded logs and the number of safety straps used in the lashing of loads:

- Treatment 1 (T1): Transportation of Pinus logs with length of $2.40 \mathrm{~m}$ using 6 security straps. (1 per package);

- Treatment 2 (T2): Transportation of Pinus logs with length of $3.40 \mathrm{~m}$ using 4 safety straps. (1 per package);

- Treatment 3 (T3): Transportation of Pinus logs with length of $3.40 \mathrm{~m}$ using 8 safety straps. (2 per package);

- Treatment 4 (T4): Transportation of Pinus logs with length of $7.00 \mathrm{~m}$ using 4 safety straps. (2 per package).
The mean times spent in each transportation operation in the different treatments were compared. Each operation had minimum number of samples for achieving sample adequacy at 15\% error limit, according to Equation 1 provided by the company research sector:

$N=\frac{c v^{2} \cdot t(a ; G L)}{L \cdot E^{2}}$

Where: $\mathrm{N}=$ Sample adequacy; $\mathrm{VC}=$ variation coefficient; $\mathrm{t}=$ inverse of student ' $\mathrm{s}$ t distribution, with certain probability, $\alpha=$ degrees of freedom, G.L $=n-1$; L.E. $=$ acceptable limit of error.

\subsection{Technical evaluation}

Technical evaluation was carried out with a study carried out on the different operation times during forest transportation, such as loading, load lashing, load unlashing and unloading. In this study, centesimal chronometer, clipboard and specific form were used.

The average forest loader productivity was given in tons per effective working hour using the following Equation 2 provided by the company:

$\operatorname{Pr}=\frac{t}{h e}$

Where: $\mathrm{Pr}=$ productivity (effective ton/hour); $\mathrm{t}=$ tons of loaded and unloaded wood (obtained through the factory scale); he = hours effectively worked.

Yield was evaluated comparing treatments with higher productivity results with treatments with lower productivity results. Values were obtained by Equation 3:

$R=\left(\frac{\operatorname{Pr} 1}{\operatorname{Pr} 2}-1\right) x 100$ 
Where: $\mathrm{R}=$ Yield (\%); Pr: productivity values obtained by Equation 2 .

The yard efficiency was determined by Equation 4 supplied by the company:

$E p=\frac{t O}{t P} x 100$

Where: $\mathrm{Ep}=$ yard efficiency; $\mathrm{tO}=$ total time of operation in the yard (unlashing, unloading and sweeping); $\mathrm{tP}=$ total time of the bi-train in the yard (obtained through scale).

The total operation time is the sum of unlatched, unloaded and swept operation times. The total yard time is the time marked on the balance system from the input of the loaded truck to the removal of a new transport note by the driver. Waiting time is the time the truck moves around the yard and/or waiting in line to unload, it is an inoperative time. The total yard time is the time set in the scale system from the entry of the loaded truck to the removal of a new transport note by the driver. Waiting time is the time when the truck moves around the yard and / or waits in line for unloading, which is the inoperative time.

\subsection{Statistical analysis}

At the end of data collection, the analysis of variance of means of treatments that reached sample adequacy was performed. For this, a completely randomized design was used. After the analysis of variance of means, the Tukey test was performed at 95\% level.

\section{RESULT AND DISCUSSION}

\subsection{Sampling adequacy}

Sampling adequacy was achieved with an average of 10 observations for each operation, considering $15 \%$ error limit and $95 \%$ probability. Table 1 shows the averages found in the study. For analysis purposes, loading and unloading activities were evaluated by separating log lengths, and the lashing and unlashing analysis considered the length and number of straps per package. The significance test showed statistical differences in all activities evaluated, with a clear improvement in times when log length is increased and the number of straps is reduced.

Table 2 shows the average weight of loaded and unloaded Pinus taeda logs, with lengths of $2.40 \mathrm{~m}$ (PTP-240), $3.40 \mathrm{~m}$ (PTP-340) and $7.00 \mathrm{~m}$ (PTP- 700), as well as the average time of each operation in minutes. Using the productivity equation, production per effective hour of work and yield among lengths was obtained.

\subsection{Influence of log length}

Length primarily influences log loading and unloading, since shorter logs require the hook to perform more loading and unloading activities.

The average time of the loading operation was 17.51 minutes, while the average total time of the unloading operation was 6.47 minutes, providing higher productivity in the unloading operation.

It could be observed that in loading and unloading activities, treatment with 2.4-meter logs took on average $113.90 \%$ more time in the loading activity and $91.89 \%$ more time in the unloading activity than in activities carried out with 7-meter logs and 40.99\% more time in loading activities and $27.16 \%$ in unloading activities with 3.4-meter logs.

Regarding the unloading activity, the results are consistent with those obtained by Alves et al. (2013), who found higher productivity in unloading operations with logs of greater length. The operation with the highest productivity was the unloading of 7.00-meter logs,, with 450.54 tons per effective working hour.

Table 1. Tukey test for the time spent in each activity.

\begin{tabular}{|ccccc|}
\hline \multirow{2}{*}{ Treatments } & \multicolumn{4}{c|}{ Means (in decimal minutes) } \\
\cline { 2 - 5 } & Loading & Unloading & Lashing & Unlashing \\
\hline T1 & $24.73 \mathrm{c}$ & $8.52 \mathrm{c}$ & $7.43 \mathrm{~b}$ & $6.29 \mathrm{~b}$ \\
T2 & $17.54^{* *} \mathrm{~b}$ & $6.70^{* *} \mathrm{~b}$ & $4.85 \mathrm{a}$ & $4.04 \mathrm{a}$ \\
T3 & $11.29 \mathrm{a}$ & $4.44 \mathrm{a}$ & $7.33 \mathrm{~b}$ & $6.08 \mathrm{~b}$ \\
T4 & & $4.87 \mathrm{a}$ & $3.94 \mathrm{a}$ \\
\hline
\end{tabular}

${ }^{*}$ Means followed by the same letter do not differ by the Tukey test with $5 \%$ probability; ${ }^{\star *}$ Means are equivalent to T2 and T3 Treatments because during loading and unloading operatons, only log lengths were analyzed; T1: Length of $2.40 \mathrm{~m}$; using 6 security straps ( 1 per package); T2: length of $3.40 \mathrm{~m}$; using 4 safety straps (1 per package); T3: length of $3.40 \mathrm{~m}$; using 8 safety straps (2 per package); T4: length of $7.00 \mathrm{~m}$; using 4 safety straps ( 2 per package). 
Table 2. Average weight, average times, productivity and length yield.

\begin{tabular}{|c|c|c|c|c|c|}
\hline \multicolumn{6}{|c|}{ Loading } \\
\hline Arrangement & Treatment & Load Weight (t) & $\begin{array}{l}\text { Time } \\
\text { (min) }\end{array}$ & Productivity ( $\mathrm{t}$ he $\mathrm{e}^{-1}$ ) & Yield (\%) \\
\hline PTP-240 & $\mathrm{T} 1$ & 43.62 & 24.73 & 105.83 & \\
\hline PTP-340 & $\mathrm{T} 2$ and $\mathrm{T} 3$ & 41.56 & 16.49 & 151.22 & 30.01 \\
\hline PTP-700 & $\mathrm{T} 4$ & 33.34 & 11.3 & 177.03 & 40.22 \\
\hline Mean & & 39.51 & 17.51 & 144.69 & \\
\hline \multicolumn{6}{|c|}{ Unloading } \\
\hline Arrangement & Treatment & Load Weight (t) & $\begin{array}{l}\text { Time } \\
\text { (min) }\end{array}$ & Productivity ( $\mathrm{t}$ he $\mathrm{e}^{-1}$ ) & Yield (\%) \\
\hline PTP-240 & $\mathrm{T} 1$ & 43.62 & 8.98 & 291.45 & \\
\hline PTP-340 & $\mathrm{T} 2$ and $\mathrm{T} 3$ & 41.56 & 5.99 & 416.29 & 29.99 \\
\hline PTP-700 & $\mathrm{T} 4$ & 33.34 & 4.44 & 450.54 & 35.31 \\
\hline Mean & & 39.51 & 6.47 & 386.09 & \\
\hline
\end{tabular}

PTP: Logs of Pinus taeda for process in Pulp and Paper Industry.

Longer time required in the loading activity is also observed, mainly because the loading area, forest roads, are influenced by unfavorable conditions when compared to the conditions of industrial yards. According to Santos et al. (2009), an important factor to reduce the loading operation efficiency are soil moisture content and travel time adjustment time, while during unloading operation, the yard situation is controlled, with flat terrain and loads already organized on bi-trains.

In a forest loading study, Santos et al. (2009) observed average productivity of 141.5 tons per effective working hour with 3.60-meter logs and average time of 18 minutes in the operation, showing that the results are within expected values found in literature, when compared to $3.40 \mathrm{~m}$ loads,, with productivity of 151.2 tons per hour and average time of 16.49 minutes.

An improvement in the loader productivity and efficiency in the three situations evaluated could be achieved by better organization of log piles at the roadside, reducing the times spent storing loads and batteries. Moreover, gains in the mechanical availability and operational efficiency of the machine can be obtained by reducing the time spent storing loads, as this activity generates great wear on machinery.

Regarding load weight, bi-trains trucks are allowed to traffic with total gross weight of 57 tons. Considering the average vehicle weight of 23 tons, the net load should not exceed 34 tons. This weight is not controlled, and vehicles are loaded up to the space limitations of the composition. However, with the increase in log length to $7.00 \mathrm{~m}$ and consequent increase in productivity, it is possible to control net weight traveling according to the law, that is, maximum weight allowed for the mode of transportation used, which is 57 tons of total gross weight.

\subsection{Influence on the number of safety straps}

Lashing and unlashing operations with safety belt straps affect the system productivity since they consume time in the transportation process.

There is an improvement in lashing and unlashing times when fewer safety straps are used. An increase in the time spent in these operations with the increase of 4 straps in T2 and T4 treatments can be observed, for the other T1 with 6 straps and T3 with 8 straps. Nevertheless, this trend was not observed between $\mathrm{T} 1$ and $\mathrm{T} 3$ treatments. This result may be explained by the influence of the number of packages in T1 and T3 treatments, which is 6 and 4, respectively.

\section{CONCLUSIONS}

The results obtained in this study allowed considering that increasing log length from $2.40 \mathrm{~m}$ to $7.00 \mathrm{~m}$ increases the loading and unloading productivity, thereby increasing the system yield.

The reduction in the number of safety straps used in the lashing of loads from two to one strap positively influenced the loading, unloading and lashing process, increasing the productivity of trucks. 


\section{SUBMISSION STATUS}

Received: 7 mar., 2017

Accepted: 24 jan., 2018

\section{CORRESPONDENCE TO}

\section{Renato Cesar Gonçalves Robert}

Universidade Federal do Paraná - UFPR, Rua

Lothário Meissner, 900, CEP 80060-000, Curitiba, PR, Brasil

e-mail: renatorobert@ufpr.br

\section{REFERENCES}

Alves RT, Fiedler NC, Silva EN, Lopes ES, Carmo FCA. Análise operacional do descarregamento de madeira com diferentes comprimentos em fábrica de celulose. Revista Científica Eletrônica de Engenharia Florestal 2013; 21(1): 1-11.
Bramucci M, Seixas F. Determinação e quantificação de fatores de influência sobre a produtividade de "harvesters" na colheita florestal. Scientia Forestalis 2002; 62: 62-74.

Costa FA, Sousa RATM, Leite AMP. Transporte rodoviário de madeira: um estudo de caso na Amazônia. In: Anais do VI Simpósio Brasileiro sobre Colheita e Transporte Florestal; 2003; Belo Horizonte. Belo Horizonte: UFV/ SIF; 2003. p. 349-363.

Machado CC, Lopes ES, Birro MHB, Machado RR. Transporte rodoviário florestal. 2. ed. Viçosa: Editora da Universidade Federal de Viçosa; 2009. 217 p.

Minette LJ, Souza AP, Fiedler NC, Silva EN. Carregamento e descarregamento. In: Machado CC. Colheita florestal. 3. ed. Viçosa: UFV; 2014

Santos MD, Lopes ES, Dias AN, Ribeiro AB. Avaliação técnica de um carregador florestal com diferentes sortimentos de madeira. Revista Ambiência 2009; 5(1): 13-26.

Strandgard M, Mitchell R. Automated Time Study of Forwarders using GPS and a vibration sensor. Croatian Journal of Forest Engineering 2015; 36(2): 175-184. 